\title{
Durability of concrete using marble mining waste
}

\author{
Kore S.D. *, Vyas A.K. \\ Department of civil engineering, Malaviya National Institute of Technology, Jaipur, Rajasthan-302017, India. \\ * Corresponding Author: suudarshankore123@gmail.com
}

Received : 30-09-2016

Revised: 09-11-2016

Accepted: 20-11-2016

\begin{abstract}
The aim of the study was to study behavior of concrete containing marble mining waste under aggressive environment. Waste from marble mining and processing industries was used in concrete as coarse aggregate in combination with conventional coarse aggregate. The particle packing density approach was followed to design the concrete mix and $75 \%$ conventional coarse aggregate was replaced by aggregate obtained by crushing waste from marble mining waste. The water-cement ratio was fixed 0.45 for all the mixes. Properties of concrete under aggressive environment such as chloride ion penetration, resistance to sulphates were evaluated. The test results revealed that, resistance to chloride ion penetration and sulphate attack increased as compared to control concrete. Overall the results supported by microstructure analysis indicate that there is no significant adverse effect on the use of marble waste as a coarse aggregate on the durability properties of concrete. The results of fire study reveal that, concrete with marble waste performs better than control concrete up to a temperature of $800^{\circ} \mathrm{C}$.
\end{abstract}

Key words: Marble Mining Waste, Cement Concrete, Durability.

\section{Introduction}

The ornamental stone industries are the backbone to the economy of Rajasthan state, India. Approximately 95\% of production of marble in India is from Rajasthan state alone (MSME, 2009; Marble, 2013). In the state of Rajasthan around 4000 marble mines and about 1100 processing units are operated. These mines and industries produce lot of waste in the form of pieces of irregular size of stones and powder/slurry. The waste generated during the mining operation is approximately $50 \%$ of the overall production (Minor Minerals, 2014; MSME, 2009). According to Jain et al. (2015) in India the solid waste generation per annum is around 48 million tons. The percentage of marble waste, as generated during mining has been estimated approximately $50 \%$ of total mass (MSME, 2009). This waste produced is huge in quantity and a little part of it is used in small scale in manufacture of tiles and statues and rest is dumped on open land, roadsides forestland, pasture lands and agricultural fields leading to widespread environmental pollution and loss of fertile top soil. Such wastes adversely affect vegetation in nearby area and create lot of environmental and health problems to the people in nearby area. This industrial waste has been used by many researchers in infrastructure development works for easy and effective disposal.

Hebhoub et al (2011) conducted studies on use of marble waste in the form of fine and coarse aggregate in concrete with water-cement ratio of 0.5 . He reported that, workability decreased with increase in replacement level in the range of $0 \%$ to $100 \%$ for all the formulations. Compressive strength of concrete mix increased by $16 \%$ to $25 \%$ at $75 \%$ replacement of conventional aggregate by marble aggregate. In a study conducted by André et al (2014), marble waste was used in different percentages (20\% to $100 \%)$ as replacement for conventional aggregates. It was reported that, workability and compressive strength of concrete mix marginally decreased as the replacement level increased. They also reported that, water absorption and depth of carbonation of concrete containing marble aggregate showed similar results to that of control concrete. Whereas the water absorption by immersion and depth of carbonation, the performance of concrete 
containing marble aggregate shows similar trend to that of control concrete. The results obtained by André et al. (2014) are in the line of the results obtained by Hebhoub et al. (2011). Marble waste used as a $100 \%$ replacement for natural coarse aggregates in concrete with a constant watercement ratio 0.4 in a study conducted by Binici et al. (2008). Fine aggregate used in their study was river sand and ground blast furnace slag. It was reported that, compressive strength, flexural strength, splitting tensile strength and young's modulus of elasticity of concrete, prepared with ground blast furnace slag as fine aggregate and marble waste as coarse aggregate was 3\% and 6\%, respectively, higher than that of concrete with river sand as fine aggregate and marble waste as coarse aggregate. Another study conducted by Binici et al. (2007) reported, compressive strength of concrete mix containing marble dust and control concrete after immersion in $10 \%$ sodium sulphate solution was reduced by $15 \%$ and $58 \%$, respectively. In a study by Abdul Mageed et al. (2014) marble waste was used as a complete replacement for conventional coarse aggregate. They reported that, the physical and mechanical properties of concrete improved. The workability of concrete mixes increased by $50 \%$ due to smooth flat surface and low water absorption of marble aggregate. It was also reported that, the compressive and flexural strength of concrete containing marble aggregate increased by $29.62 \%$ and $11.44 \%$ as compared to that of control mix. Kore and Vyas (2016-a) conducted studies on use of marble waste as a partial replacement for conventional coarse aggregates in different percentages $(0 \%$ to $100 \%)$ in low strength concrete mixes designed as per Bureau of Indian Standards (BIS) guidelines. From this study it was observed that, the workability of all the concrete mixes increased with increase in replacement level. The compressive strength of the concrete mixes increased by $35 \%$ and $26 \%$, respectively at $80 \%$ and $100 \%$ replacement level of conventional coarse aggregate. Martins et al. (2014) reported that, coarse aggregate from marble waste can be used as a partial replacement for conventional coarse aggregate to improve the mechanical properties of concrete. They also reported that, the workability of all concrete mixes increased by $4.16 \%, 2.08 \%, 9.34 \%$ and density marginally decreased by $0.28 \%, 1.49 \%$ and $4.21 \%$ at $20 \%, 50 \%$ and $100 \%$ replacement level respectively. With regard to compressive and tensile strength, both marginally decreased by $5.2 \%, 2.3 \%, 6.2 \%$ and $10.4 \%, 6.1 \%, 1.0 \%$ respectively but this decrease was approximately $10 \%$ and found to be insignificant. It was also reported that, concrete mixes prepared using marble waste showed reduction in abrasion resistance by $9.3 \%, 18.1 \%$ and $26.8 \%$ at $20 \%, 50 \%$ and $100 \%$ replacement level.

In the present study, concrete mixes were designed keeping a constant water cement ratio of 0.45 and maximum packing density of aggregates. Durability properties of concrete supported by microstructure have been discussed.

\section{Experimental study}

\subsection{Characterization of materials}

Portland Pozzolana cement used in this study fulfills the requirement of BIS:1489 (1991). The marble waste used in this study was brought from the mining areas, then it was fed into crusher to obtain the desired gradation suitable for coarse aggregate. The fine aggregate, conventional coarse aggregate and aggregate produced from marble mining waste conform to grading zone II as per BIS 383 (1997). The nominal maximum size of conventional coarse aggregate and marble aggregate used was $20 \mathrm{~mm}$. The particle size distributions of aggregates are shown in Figure 1. The physical properties of fine and coarse aggregates used in this study are presented in Table 1. The chemical compositions of coarse aggregates are presented in Table 2. In order to achieve desired slump of 75 $\mathrm{mm}$, a third generation poly-carboxylate based super-plasticizer Rheobuild 522 ND confirming to BIS:9103 (1999) was used. From Table 1 it was observed that, water absorption of marble mining waste is less that of conventional aggregate. The values obtained in Los Angeles test are within the limits as per BIS: 2386 (1963). 
Table 1. Physical properties of aggregates.

\begin{tabular}{ccccc}
\hline Aggregate type & Specific gravity & $\begin{array}{c}\text { Water absorption } \\
(\%) \text { by weight }\end{array}$ & Grading zone & $\begin{array}{c}\text { Los Angeles abrasion } \\
\text { value (\%) }\end{array}$ \\
\hline \hline $\begin{array}{c}\text { Coarse conventional } \\
\text { aggregate }\end{array}$ & 2.78 & 0.54 & As per Table 2 of BIS & 25.88 \\
$\begin{array}{c}\text { Fine aggregate } \\
\begin{array}{c}\text { Coarse aggregate } \\
\text { from marble mining } \\
\text { waste }\end{array}\end{array}$ & 2.66 & 2.0 & $\begin{array}{c}\text { Zone II As per Table } 4 \\
\text { of BIS 383 }\end{array}$ & - \\
\hline
\end{tabular}

Table 2. Chemical compositions as percentage of oxides in marble maste and natural aggregate.

\begin{tabular}{ccc}
\hline Component & Marble mining waste (\%) & Natural aggregate (\%) \\
\hline \hline $\mathrm{SiO}_{2}$ & 3.75 & 53.70 \\
$\mathrm{CaO}$ & 33.12 & 4.83 \\
$\mathrm{MgO}$ & 17.91 & 2.01 \\
$\mathrm{Fe}_{2} \mathrm{O}_{3}$ & 0.13 & 10.66 \\
$\mathrm{Al}_{2} \mathrm{O}_{3}$ & Traces & - \\
Sulphate content & - & - \\
LOI & 45.07 & 5.08 \\
\hline
\end{tabular}

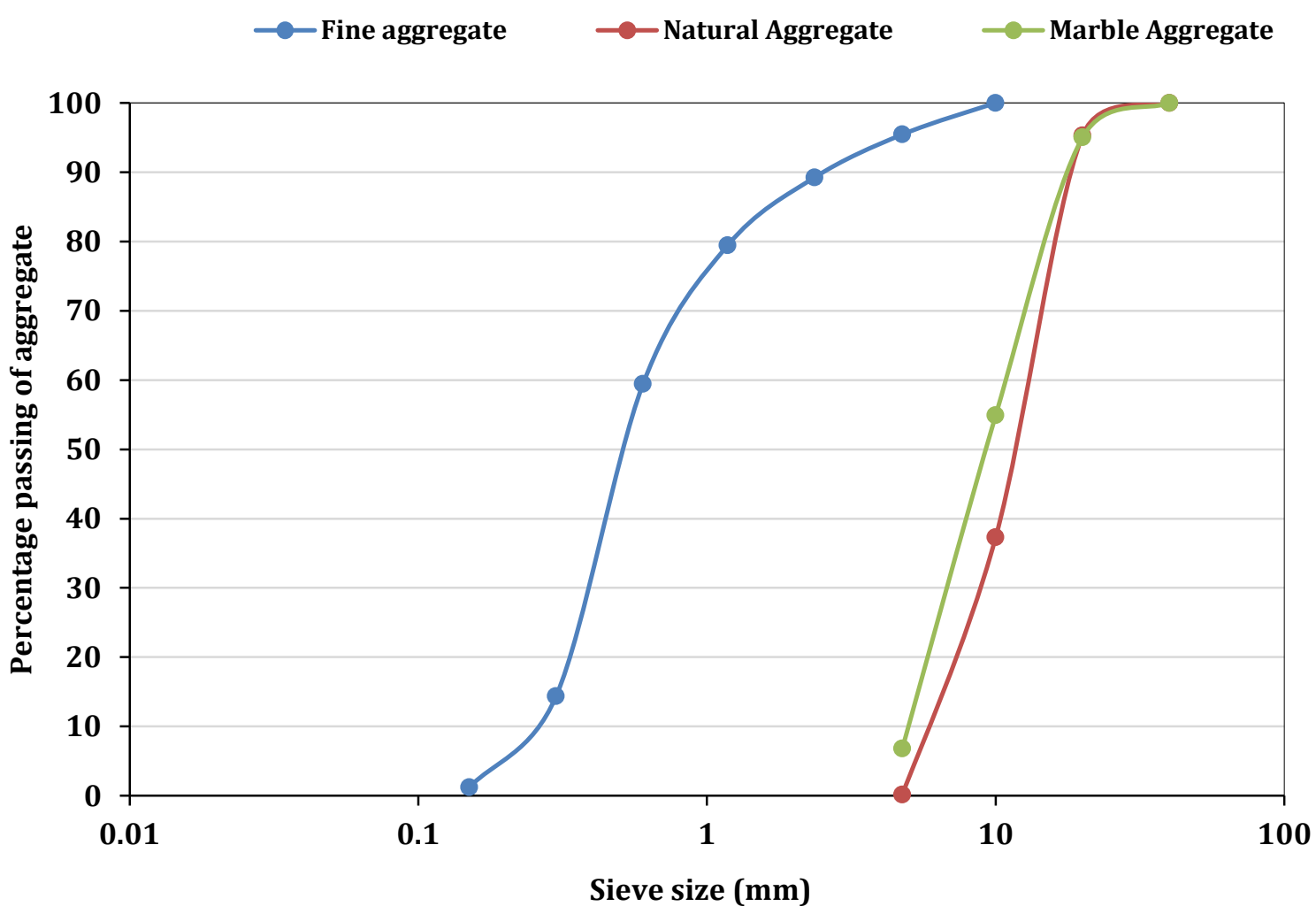

Fig 1. Particle size distribution of aggregates.

\subsection{Concrete Mix Proportioning}

The concrete mix was designed by particle packing density approach (Kore and Vyas, 2016-b). Coarse aggregate consist of $75 \%$ fraction from marble waste and $25 \%$ conventional aggregate as per best results obtained by the authors in trial mixes. All the concrete mixes were prepared with a 
constant water-cement ratio of 0.45 . Mix proportion of concrete was based on achieving maximum packing density of all aggregate by trials conducted in the laboratory.

It was found that, mixing of $60 \%$ coarse aggregate and $40 \%$ of fine aggregate resulted in maximum packing density of aggregate. The voids were estimated to be $23 \%$ in the dry aggregate mixture. Then cement paste $10 \%$ in excess of voids was mixed to the aggregate in concrete mixer in order to get desired workability in the range of $75 \mathrm{~mm}$ to $100 \mathrm{~mm}$. The mixture proportions are given in Table 3.

Table 3. Mix Proportion.

\begin{tabular}{|c|c|c|c|c|c|c|c|c|}
\hline \multirow{3}{*}{ Mix } & \multirow{3}{*}{$\begin{array}{l}\text { Paste content } \\
\text { in excess of } \\
\text { voids }(\%)\end{array}$} & \multirow{3}{*}{$\begin{array}{l}\text { Water } \\
\text { (l) }\end{array}$} & \multirow{3}{*}{$\begin{array}{l}\text { cement } \\
(\mathrm{kg})\end{array}$} & \multirow{3}{*}{$\begin{array}{l}\text { sand } \\
(\mathrm{kg})\end{array}$} & \multicolumn{4}{|c|}{ Coarse aggregate (kg) } \\
\hline & & & & & \multicolumn{2}{|c|}{ Natural aggregate } & \multicolumn{2}{|c|}{$\begin{array}{c}\text { Aggregate from marble } \\
\text { mining waste }\end{array}$} \\
\hline & & & & & $20 \mathrm{~mm}$ & $10 \mathrm{~mm}$ & $20 \mathrm{~mm}$ & $10 \mathrm{~mm}$ \\
\hline $\mathrm{C} 1$ & 10 & 157 & 348 & 800 & 720 & 481 & - & - \\
\hline $\mathrm{C} 2$ & 10 & 154 & 343 & 805 & 181 & 121 & 544 & 362 \\
\hline
\end{tabular}

Note: Mix designated by $C 1$ shows control mix and mix designated by $C 2$ shows concrete mix containing $75 \%$ marble aggregate and 25\% conventional coarse aggregate. Both the concrete mixes were designed by packing density approach.

\subsection{Sample preparation and test methods}

Cubes of size $100 \times 100 \times 100 \mathrm{~mm}$ were cast (BIS:516, 1959) to determine chloride penetration, carbonation, resistance to sulphates and resistance to fire respectively. All the specimens were demoulded at the age of $24 \pm 1 \mathrm{~h}$ and thereafter, were cured in water tank at room temperature up to 28 days. After 28 days specimens were taken out from the water, dried in oven at temperature of $60 \pm 5{ }^{\circ} \mathrm{C}$ for $24 \pm 1 \mathrm{hr}$. The specimens removed from the oven are allowed to cool down to room temperature and these dried specimens were used for further test.

\subsubsection{Permeability}

In order to assess the porosity in concrete, water permeability test was conducted as per German standard DIN-1048 (1991). The concrete specimens were kept in oven to achieve the constant weight. The concrete specimens were taken out from the oven after $24 \mathrm{~h} \pm 1 \mathrm{hr}$ and cooled down to room temperature. The weight of the specimens was measured. These specimens were exposed to a constant water pressure of $0.5 \mathrm{~N} / \mathrm{mm}^{2}$ acting normal to the mould-filling direction, for a period of $72 \mathrm{hr}$. The pressure is maintained for $72 \mathrm{hr}$. with periodic monitoring. After $72 \mathrm{hr}$. the specimens were taken out from the setup and split in to two pieces. The depth of penetration is measured.

\subsubsection{Chloride penetration Test}

The chloride penetration test was conducted on 28 days cured $(100 \times 100 \times 100 \mathrm{~mm})$ concrete specimens. The silver nitrate spraying method was followed to study the depth of penetration (Baroghel-Bouny et al., 2007-a; 2007-b). The concrete cubes were soaked in 4\% $\mathrm{NaCl}$ solution and taken out from the solution after 28, 56 and 91 days of interval. These cubes were broken in to two pieces and the $0.1 \mathrm{~N}$ silver nitrate solution was sprayed on the broken pieces.

The sprayed silver nitrate reacts with the free chloride ions present on the concrete surface and form a white precipitate of silver chloride. In the places where the free chlorides are absent, $\mathrm{AgNO}_{3}$ reacts with hydroxide to form a brown precipitate of silver oxide (AgO). Thus, the boundary of color change indicates the depth of chloride penetration as shown in Figures 2 (a) and 2 (b). 


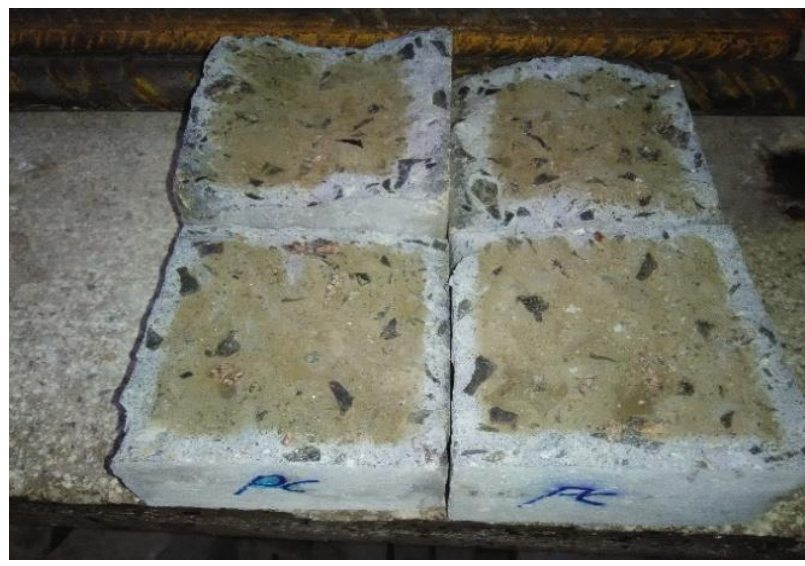

(a) Mix C1

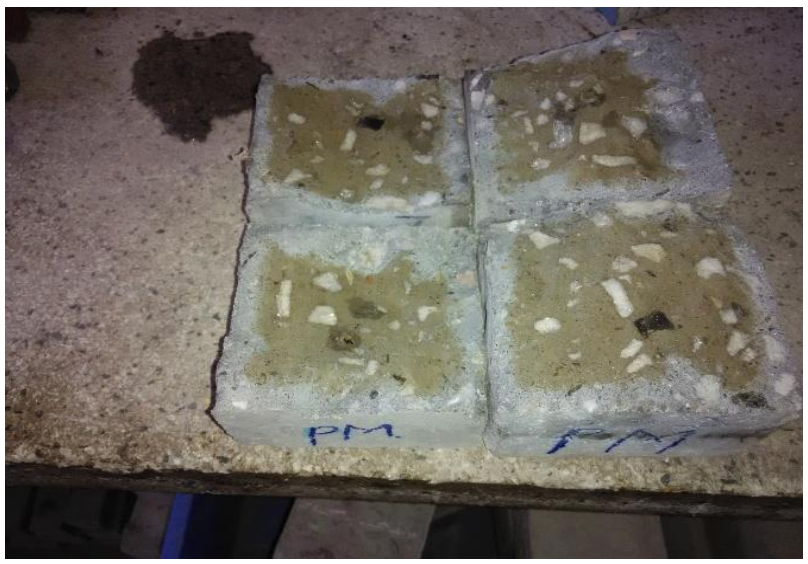

(b) MixC2

Fig 2. Images of chloride ion penetration of concrete.

\subsubsection{Resistance to Sulphate Attack}

The resistance to sulphate attack was evaluated as per ASTM C 267-01(2006). The concrete specimens were immersed in $10 \%$ dilute magnesium sulphate solution. The change in weight and compressive strength of concrete specimens was determined after 28, 56, 91, 180 and 300 days.

\subsubsection{Micro structural Analysis}

The X-ray diffraction method was adopted for the identification of most probable phases of control concrete and concrete with marble waste.

\subsubsection{Fire Exposure}

The impact of fire on the performance of concrete was investigated. The gas fired furnace was used for the experimentation. The test was carried out on the cube size specimens of $100 \times 100 \times 100 \mathrm{~mm}$ and the temperatures range is set to be $200^{\circ} \mathrm{C}, 400^{\circ} \mathrm{C}, 600^{\circ} \mathrm{C}$ and $800^{\circ} \mathrm{C}$ ( $\mathrm{Li}$ et al., 2004).

When specimens inside the furnace reached the peak temperature, fire was stopped, immediately and these specimens were taken out from furnace and allowed to cool down at room temperature. The compressive strength test was conducted on the specimens after it reached to room temperature.

\section{Results and discussion}

\subsection{Compressive strength}

The variations in the compressive strength of concrete mixes with different curing ages are shown in Figure 3. The reduction in compressive strength of concrete mix C2 was in the range of 5\% - 10\% as compared to that of control mix. But this reduction is considered as insignificant. However this is due to presence of inadequate fractions finer than $10 \mathrm{~mm}$ in marble aggregate.

Another possible reason is round shape of marble aggregate as compared to conventional coarse aggregate at similar water-cement ratio. Both the factors are responsible for fall of compressive strength in $\mathrm{C} 2 \mathrm{mix}$. 


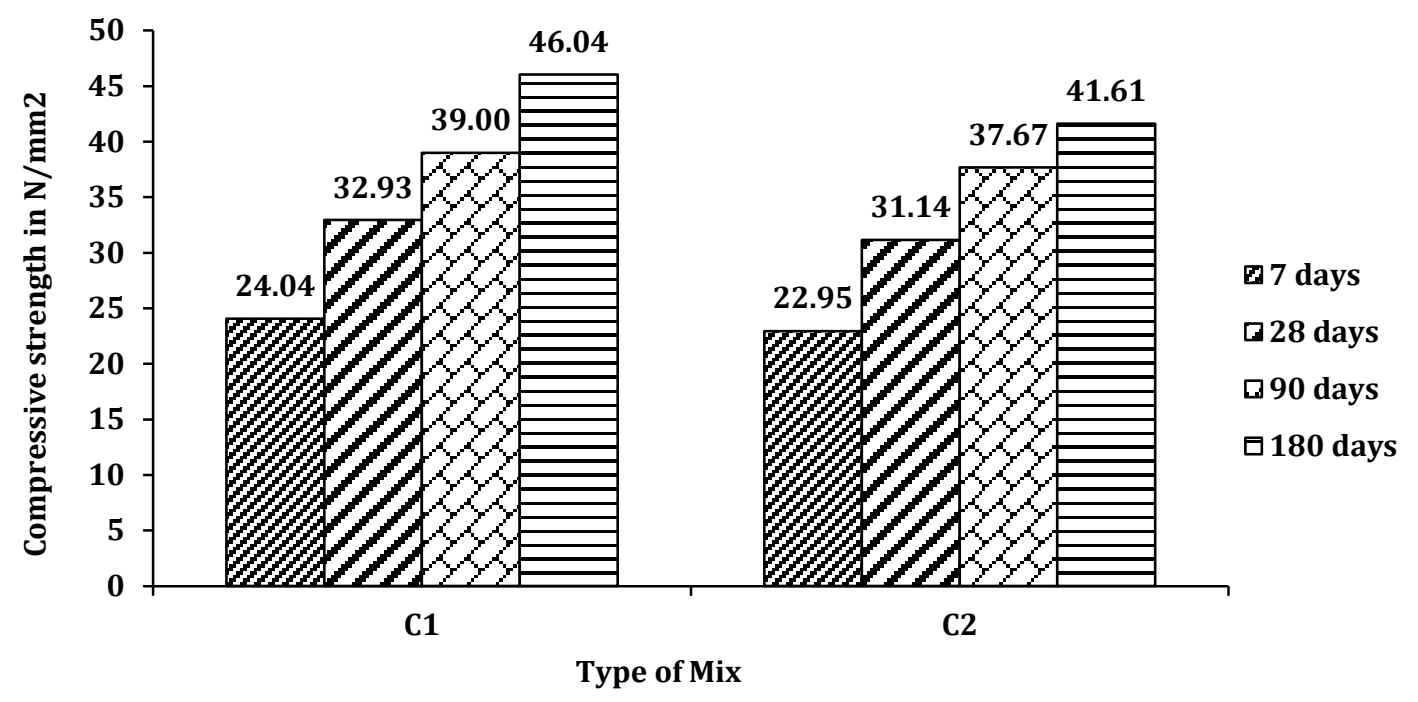

Fig 3. Variation in compressive strength of concrete.

\subsection{Permeability}

The permeability of concrete depends on interconnectivity of pores in the concrete. The permeability of $\mathrm{C} 2$ mix reduced by $8 \%$ as compared to that of control mix $\mathrm{C} 1$. The aggregates which are flaky, elongated, angular, and unfavorably graded particles lead to higher voids content than, cubical, rounded, and, well graded particles (De Larrard, 2009; Quiroga and Fowler, 2004). Possible reason for reduction in permeability of concrete mix C2 was, better packing of aggregate due to cubical and round shape of marble aggregate. Reduced permeability indicates increased durability of concrete mixes with marble waste.

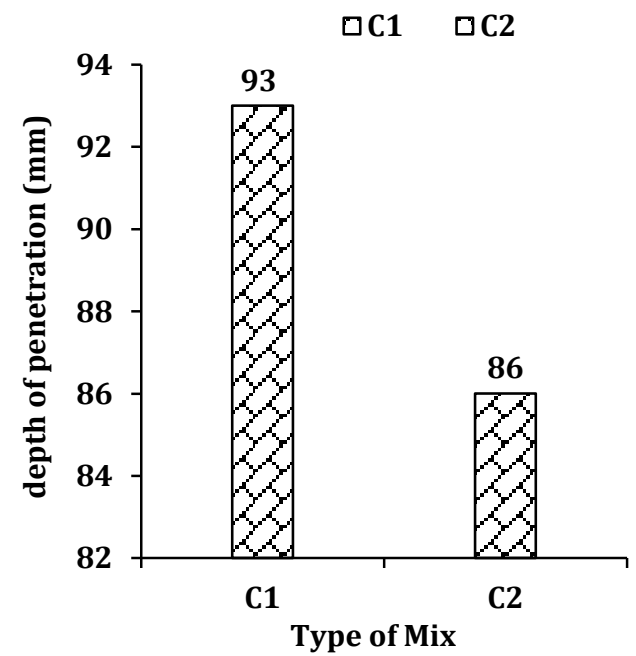

Fig 4. Variation in depth of water penetration.

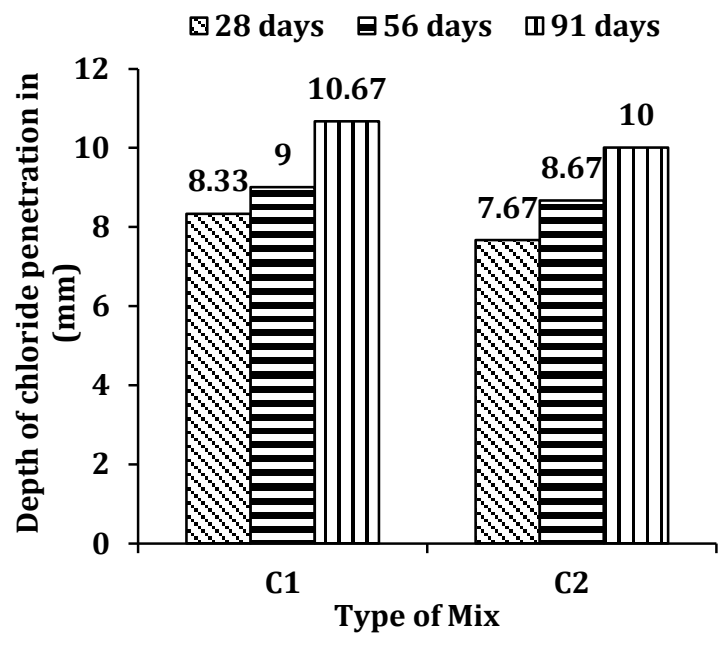

Fig 5. Variation in depth of chloride of concrete penetration

\subsection{Chloride Penetration}

Silver nitrate spray test was used to measure the depth of chloride ion penetration. The depth of penetration was obtained by measuring the average depth in three samples. The variations in the results of depth of chloride ion penetration are shown in Figure 5. 
It can be seen from the Figure 5 that, the depth of chloride ion penetration at 28 days of the concrete mix C2 was reduced by $8.6 \%, 3.8 \%$ and $6.7 \%$ in comparison to that of C1 mix at 28 days, 56 days and 91days, respectively. The significant reduction in the depth of chloride ion penetration was observed in the concrete mix C2. This reduction was due to presence of $\mathrm{Al}_{2} \mathrm{O}_{3}$ in the marble aggregates as shown in Table 2. The presence of alumina favors the formation of aluminate hydrates, which fixes the chloride ions and forms insoluble compounds (André et al., 2014). The same fact was reported by Binici et al. (2008) in their study.

\subsection{Resistance to Sulphates}

The effect of magnesium sulphate on the compressive strength of concrete specimens was studied. The results of variation in compressive strength of concrete specimens after immersion in $10 \%$ dilute magnesium sulphate solution at different ages are shown in Figure 6.

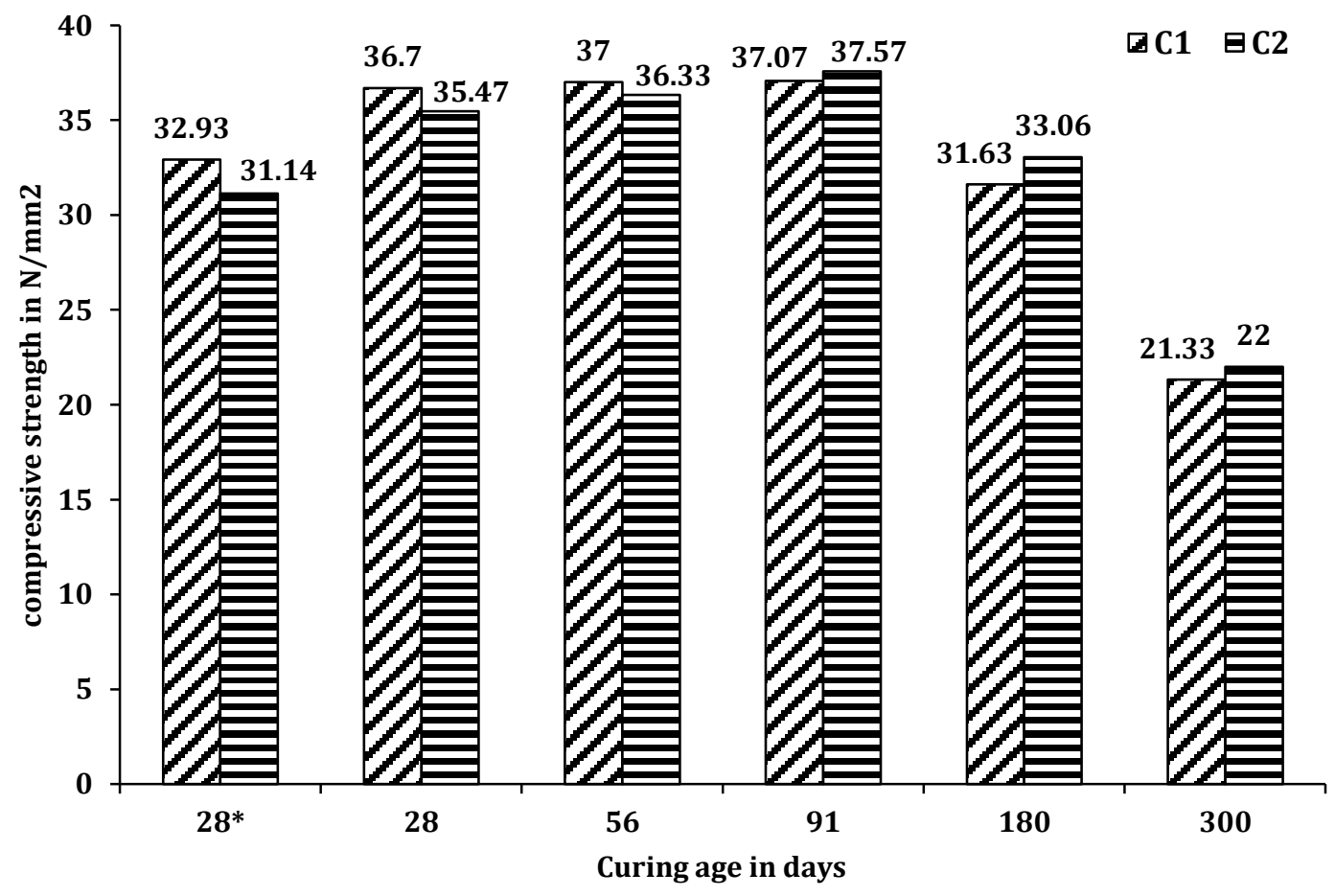

Fig 6. compressive strength of concrete after immersion in magnesium sulfate solution.

Note: *- without sulfate attack

It can be seen from Figure 6 that, initially the compressive strength of concrete specimens increased up to immersion period of 91 days. Thereafter decrease in the strength was observed as the immersion period extended to 300 days. Initial increase in strength was due to filling of pores by ettringite. Exposure of test specimens beyond 91 days shows reduction in compressive strength. This reduction in compressive strength was due to excessive formation of gypsum and ettringite which causes expansion and disruption of the concrete as shown in Figure 9.

During the test up to 91 days of immersion period no spalling or cracks on test specimens were observed except a few white patches of sulphate compounds. However after 91 days of immersion in solution, erosion and cracks on surface of the concrete were observed as seen in Figure 7, Figure 8 and Figure 9. 


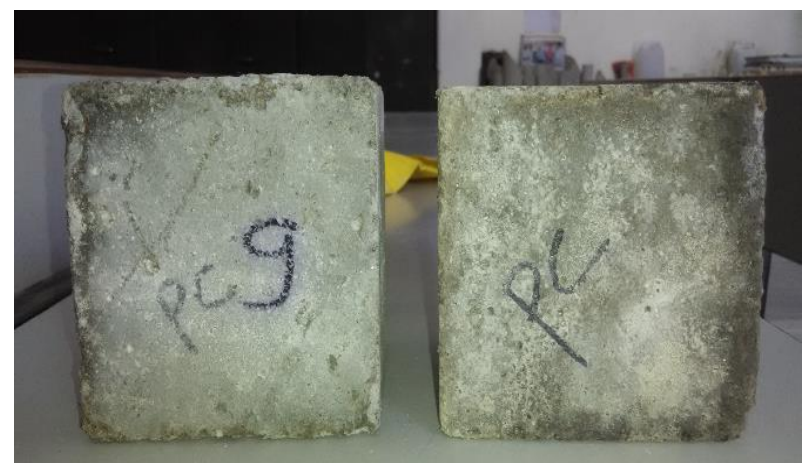

(a) Mix C1

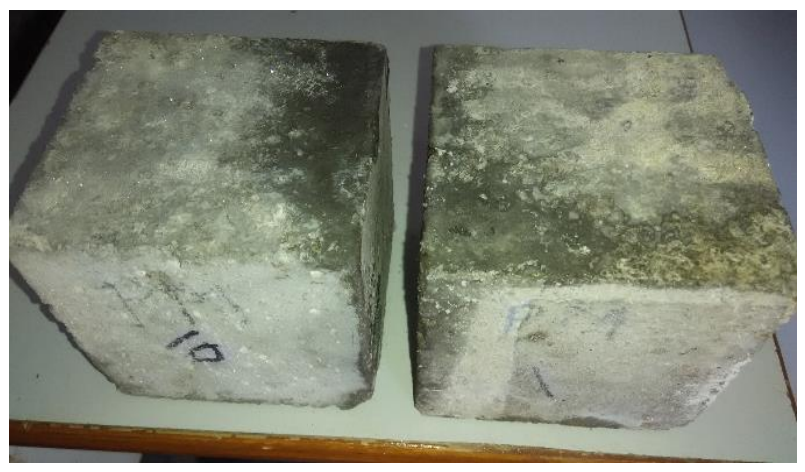

(b) Mix C2

Fig 7. After 91 days of immersion in $10 \%$ magnesium sulphate solution.

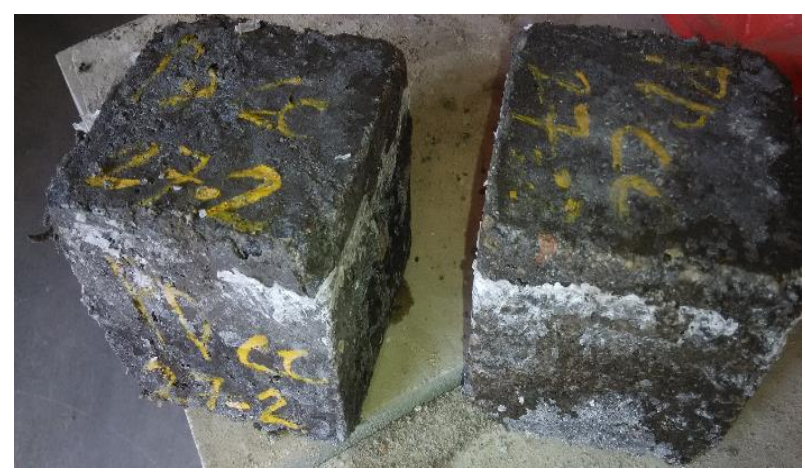

(a) Mix C1

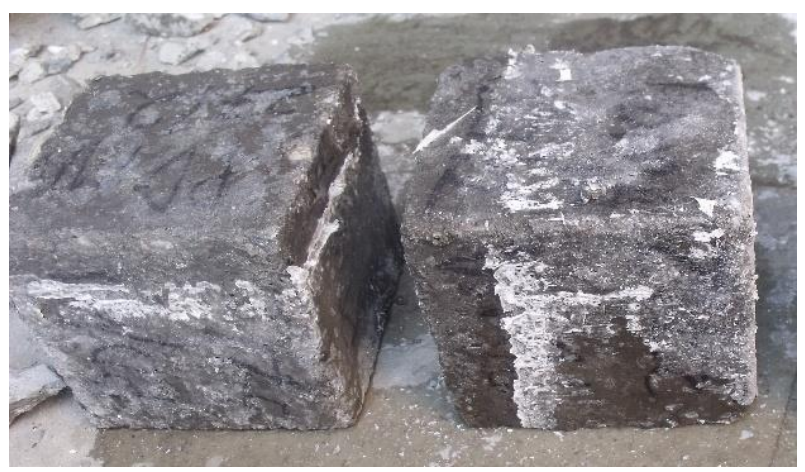

(b) Mix C2

Fig 8. After 180 days of immersion in $10 \%$ magnesium sulphate solution.

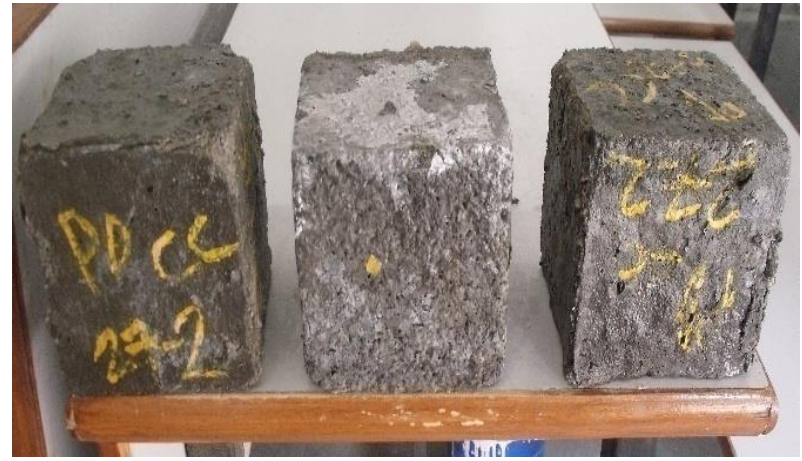

(a) Mix C1

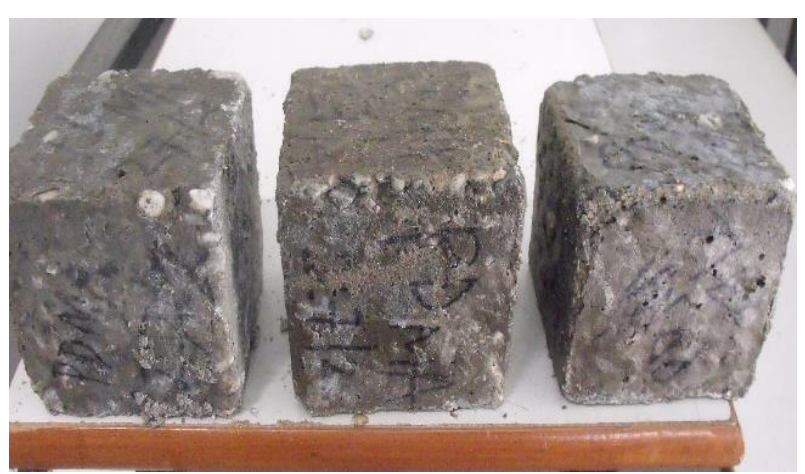

(b) Mix C2

Fig 9. After 300 days of immersion in $10 \%$ magnesium sulphate solution.

\subsection{XRD phase identification}

The powder sample of concrete mixes after 180 days of immersion in $10 \%$ magnesium solution was taken from the concrete specimens to know the most possible phases of the compounds formed during the entire immersion period. The X-ray diffraction pattern of concrete mix C1 and mix C2 are shown in Figures 10(a) and 10(b). 


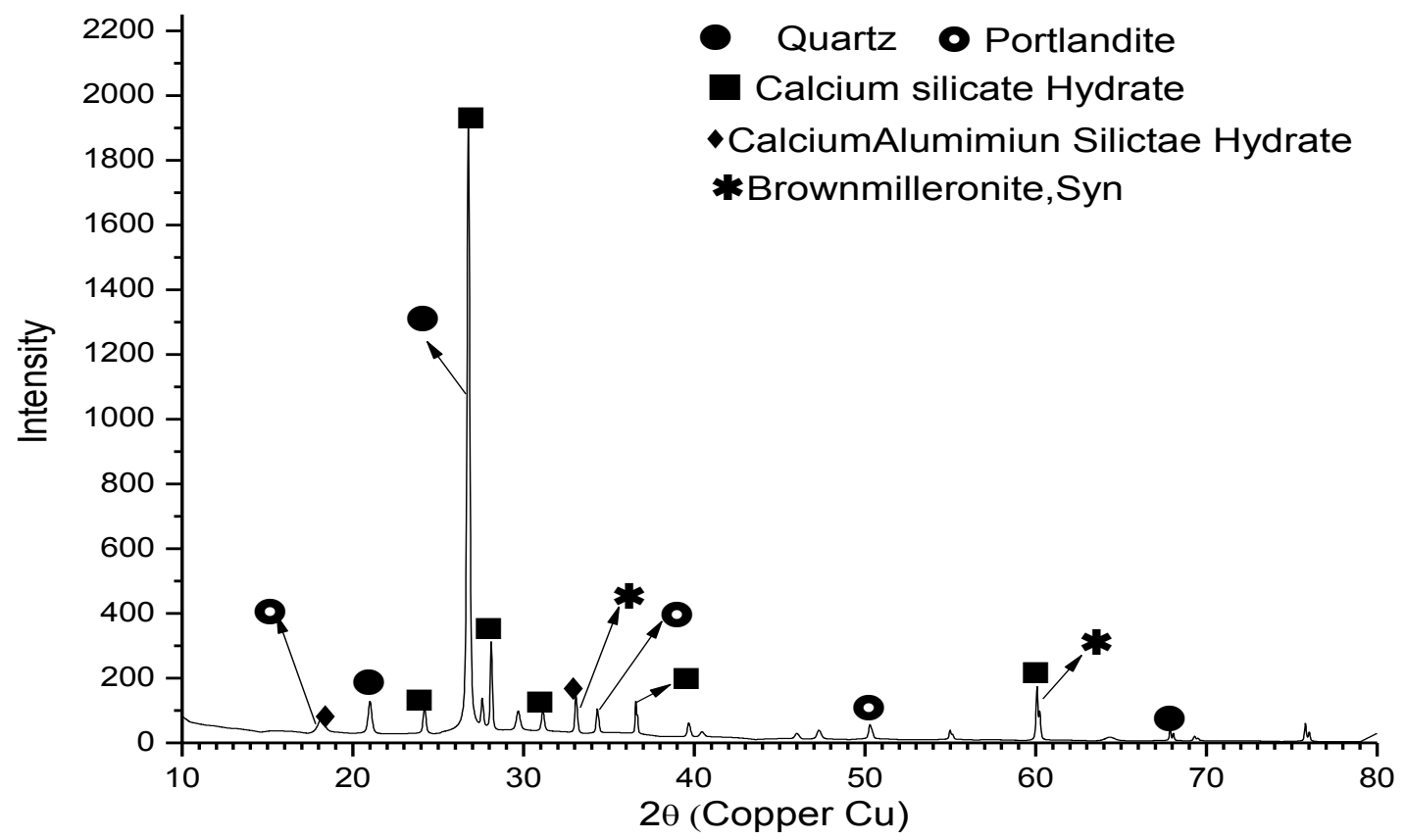

(a) Mix C1

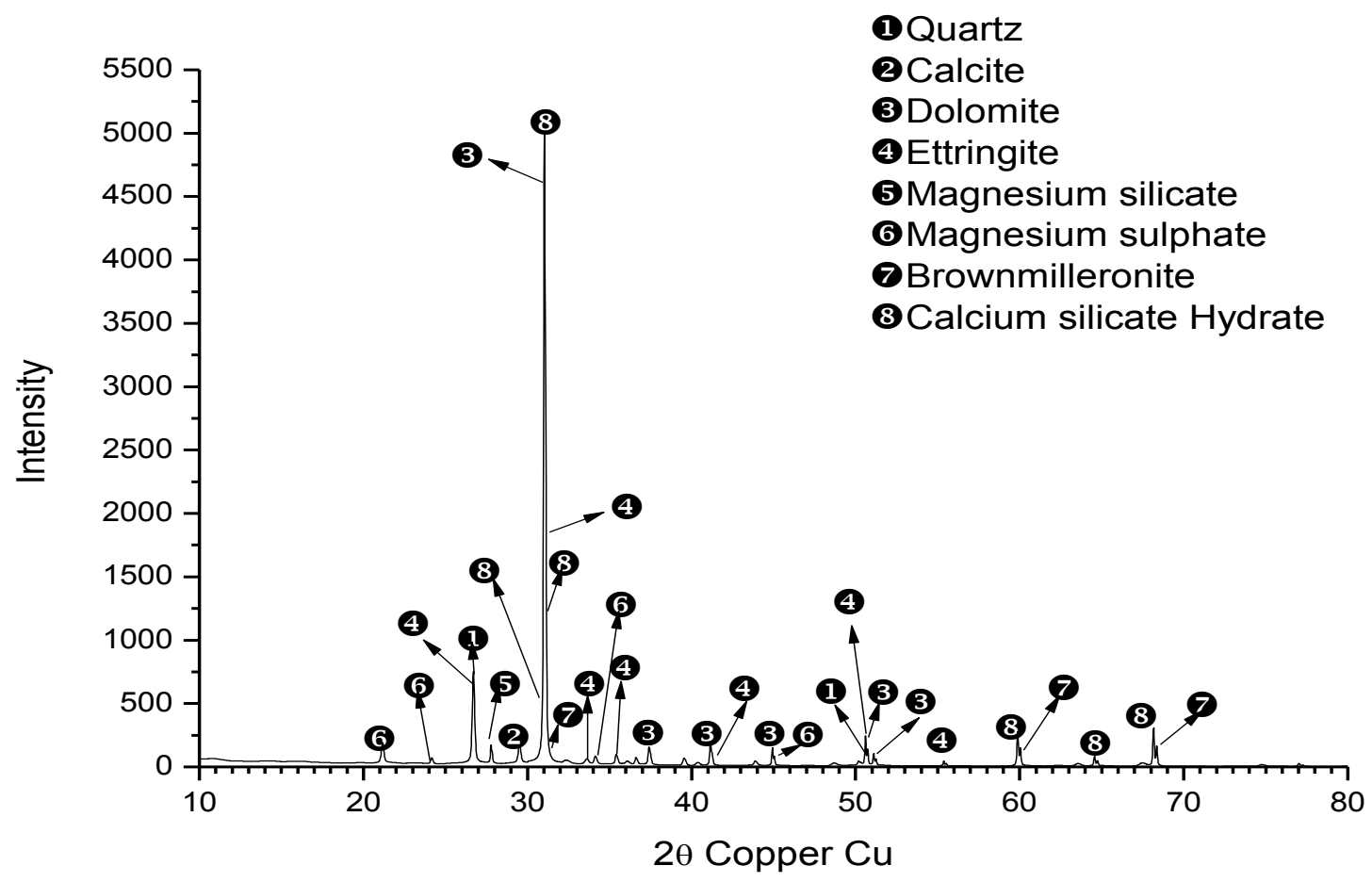

(b) Mix C2 
Fig 10. XRD of concrete after exposed to $10 \%$ MgSO4 solution at 180 days.

From the analysis it was observed that, the major compounds Dolomite and Ettringite are found in concrete containing marble aggregate i.e. mix C2. Dolomite is a calcium magnesium carbonate with a chemical composition of $\mathrm{CaMg}\left(\mathrm{CO}_{3}\right)_{2}$. Formation of Dolomite is due to presence of higher content $\mathrm{CaO}$ and $\mathrm{MgO}$ in the marble aggregate as shown in Table 2. The bond between aggregate and cement paste is improved due to presence of dolomite resulting in increase in compressive strength of concrete mix C2. This fact was also reported by Heboub et al. (2011).

\subsection{Scanning Electron Microscope (SEM) analysis}

The SEM study was conducted on the concrete specimens immersed in magnesium sulphate solution over a period of 180 days as shown in Figures 11(a) and 11(b).

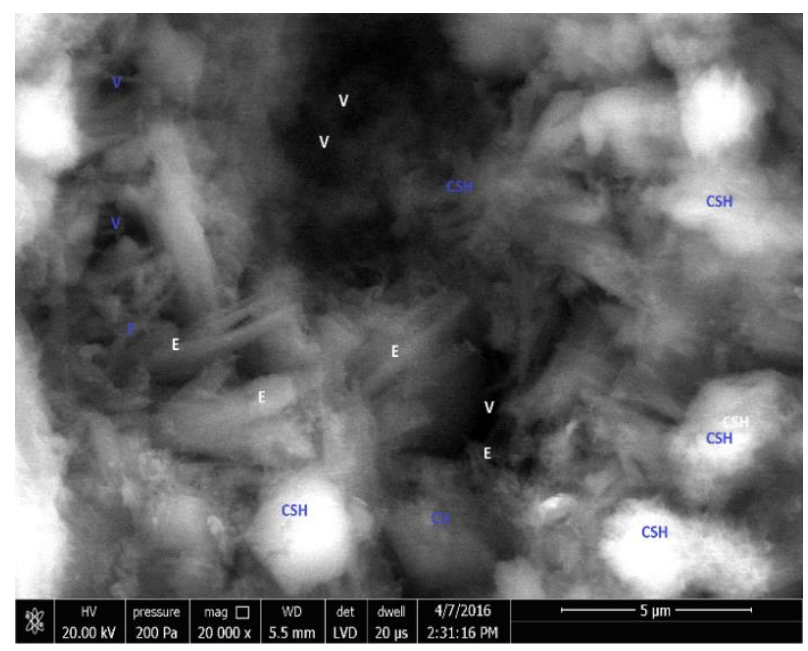

(a) Mix C1

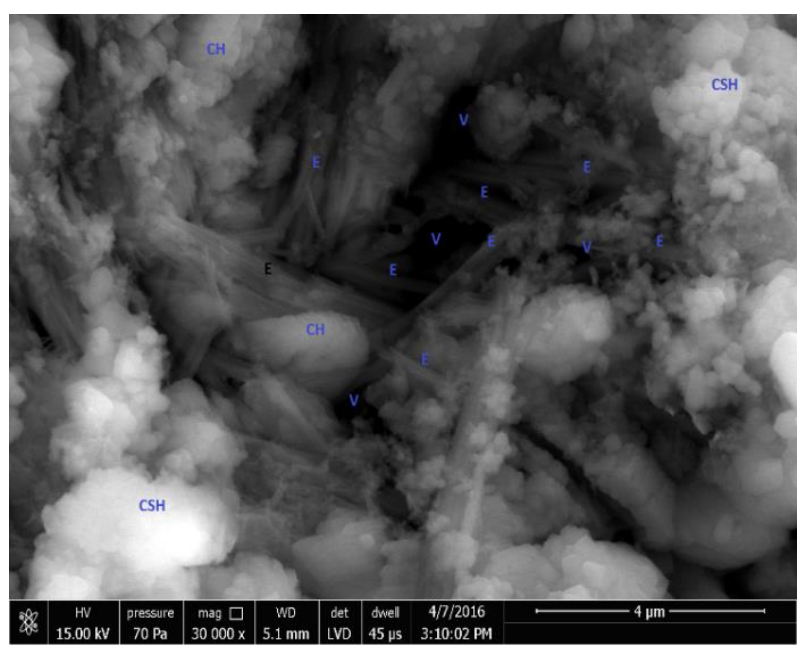

(b) Mix C2

Fig 11. SEM micrographs of concrete mixes after 180 days of immersion in $10 \%$ magnesium sulphate solution.

[E=Ettringite, $\mathrm{CH}=$ Calcium Hydroxide, $\mathrm{CSH}=$ Calcium Silicate Hydrate, $\mathrm{V}=$ voids]

The SEM images of concrete mix C1 and C2 show the formation of ettringite, CSH gel, CH crystals and voids present in the concrete. The needle shaped crystals of ettringite are seen in both the mixes. The voids seen in the concrete mix C2 are less as compared to that of control mix. The formation of these voids was due to weakening of cement matrix by entry of solution and formation of errtingite (Neville, 2004). The formation of ettringite causes volume expansion within the voids resulting in spalling (Mehta and Monteiro, 2001) and finally cracks were formed on the surface of the concrete. Because of this reason concrete losses it's mass and strength.

\subsection{Compressive strength after exposure to fire}

The impact of fire on the compressive strength of concrete specimens is shown in Figure 12. Gradual decrease in compressive strength of all concrete mixes is clearly seen as the temperature increases. The compressive strength of concrete mix C1 decreased by 15\%, 17\%, 31\% and 42\% on the other hand in mix C2 it decreased by $11 \%, 17 \%, 25 \%$ and $44 \%$ at $200{ }^{\circ} \mathrm{C}, 400{ }^{\circ} \mathrm{C}, 600{ }^{\circ} \mathrm{C}$ and $800{ }^{\circ} \mathrm{C}$ respectively. The loss in compressive strength at $200^{\circ} \mathrm{C}$ is due to evaporation of free moisture which reduces the cohesive forces. Further increase in temperature results in more loss in compressive strength due to breaking of some siliceous aggregate. Beyond $573^{\circ} \mathrm{C}$ some chemical changes in the cement and phase transformation in aggregate takes place. At this temperature the decomposition of calcium hydroxide into calcium oxide starts (Mendes et al., 2011) and chemically bound water from the $\mathrm{C}-\mathrm{S}$-H gel evaporates results in shrinkage of cement paste and formation of micro-cracks and cracks (Hager, 2013). Better performance of $\mathrm{C} 2 \mathrm{mix}$ at $600^{\circ} \mathrm{C}$ is due to the fact that 
marble remains stable up to $600^{\circ} \mathrm{C}$ and it decomposed in $\mathrm{CaO}$ and $\mathrm{CO}_{2}$ beyond temperature of $700^{\circ} \mathrm{C}$. Continuous heating of test specimens cause further fall in strength of $\mathrm{C} 2$ mixes around $800^{\circ} \mathrm{C}$ as marble aggregate start deteriorating. The breaking of calcium carbonate into calcium oxide takes place after $660{ }^{\circ} \mathrm{C}$ with the release of carbon di oxide. The reaction is endothermic, which absorbs heat and delay temperature rise in concrete. The calcined minerals are better insulator. The release of carbon di oxide from the surface of the concrete in considerable volume forms as inert insulation layer which retard the further rise of temperature (ASTM, 1956). This may be the reason for better performance of concrete containing marble aggregate (mix C2) exposure to fire. The cracks formed due to shrinkage of cement paste get widen with increase in temperature and weakens the cementaggregate bond resulting in failure of concrete showing higher loss in compressive strength.

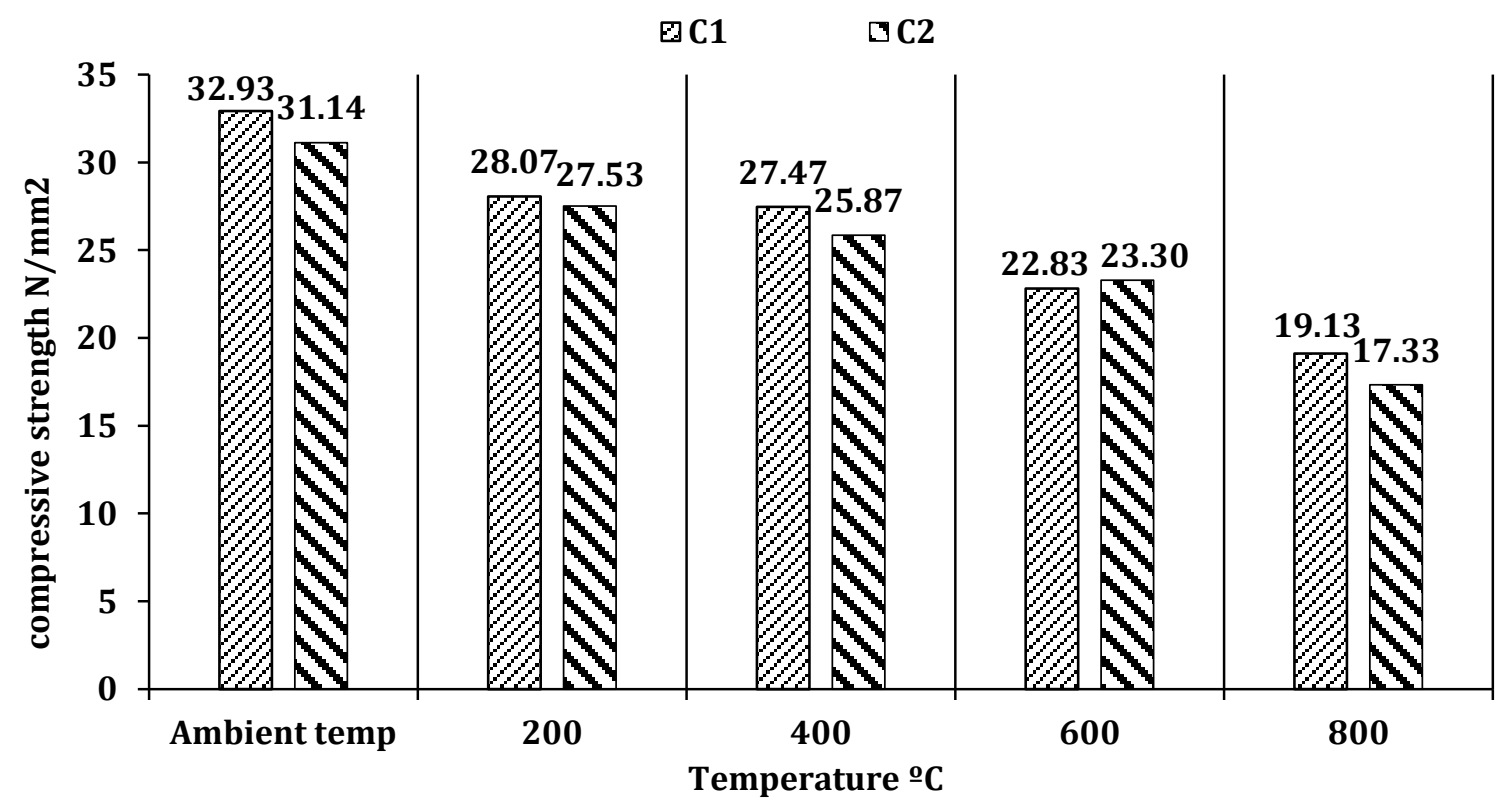

Fig 12. Compressive strength of concrete after exposure to fire.

\subsection{Cost analysis and benefits of using marble mining waste}

The cost analysis of the control concrete and concrete containing marble mining waste is shown in Table 4.

Table 4. Total material cost for production of $1 \mathrm{~m} 3$ of concrete in (INR).

\begin{tabular}{ccccccc}
\hline Mix & Water & Cement & Sand & $\begin{array}{c}\text { Natural } \\
\text { aggregate }\end{array}$ & $\begin{array}{c}\text { Marble } \\
\text { aggregate }\end{array}$ & $\begin{array}{c}\text { Total material } \\
\text { cost (Rs.) }\end{array}$ \\
\hline \hline C1 & - & $1949 /-$ & $425 /-$ & $488 /-$ & - & $2862 /-$ \\
C2 & - & $1920 /-$ & $425 /-$ & $98 /-$ & $317 /-$ & $2760 /-$ \\
\hline
\end{tabular}

From the Table 4, it can be seen that, the overall production cost of concrete mix C2 reduced by approximately $7 \%$. On the other hand the cost of natural aggregate saved by $75 \%$ as compared to that of control mixes.

In view of test results obtained it is clearly understood that, using aggregate from marble waste in place of conventional aggregate, the properties of concrete mixes are not adversely affected. The variation in properties lies in a narrow range of $+5 \%$ to $-5 \%$. The benefit shall be in terms of cost saving of concrete product and more important would be utilization of waste in that locality. Another saving would be saving in cost of disposal of waste. Such unaccounted gains keep the environment clean. 


\section{Conclusions}

In this paper concrete mixes containing marble mining waste as coarse aggregate were studied and it can be concluded that,

a) The compressive strength of concrete mixes prepared using marble mining waste are nearly equal to that of control concrete.

b) Reduction in permeability by $8 \%$ of concrete produced using marble mining waste is the indication for better durability in the future.

c) The reduction in the depth of chloride ion penetration by $8 \%$ at 28 days was observed in the concrete mix containing marble aggregate.

d) The concrete containing marble aggregate shows marginally better performance as compared to that of control concrete when concrete is exposed to sulphates.

e) After exposure to fire at different temperatures the loss in compressive strength of concrete mix C2 showed nearly same trend as that of control mix C1.

Overall the results of this study show that, marble waste can be used as aggregate in adverse environment without notable adverse effect in concrete mixes.

\section{References}

Abdul Mageed, A., Hassan, K., Mohamed, A., \& Ahmed, S. (2014). An experimental study on the availability of solid waste of mines and quarries as coarse aggregate in concrete mixes, Journal of Engineering Sciences, Assiut University, 42 (3), 876-890.

André, A., de Brito, J., Rosa, A., \& Pedro, D. (2014). Durability performance of concrete incorporating coarse aggregates from marble industry waste. Journal of Cleaner Production, 65, 389-396.

ASTM (1956). Significance of tests and properties of concrete and concrete aggregates. ASTM special technical publication, $\mathrm{N}^{\circ} 169$, Philadelphia, $\mathrm{Pa}$.

ASTM C267-01(2006), Standard Test Methods for Chemical Resistance of Mortars, Grouts, and Monolithic Surfacings and Polymer Concretes, ASTM International, West Conshohocken, PA, 2006, www.astm.org.

Baroghel-Bouny, V., Belin, P., Maultzsch, M., \& Henry, D. (2007-a). AgNO3 spray tests: advantages, weaknesses, and various applications to quantify chloride ingress into concrete. Part 1: Non-steady-state diffusion tests and exposure to natural conditions. Materials and structures, 40(8), 759-781.

Baroghel-Bouny, V., Belin, P., Maultzsch, M., \& Henry, D. (2007-b). AgNO3 spray tests: advantages, weaknesses, and various applications to quantify chloride ingress into concrete. Part 2: Non-steady-state migration tests and chloride diffusion coefficients. Materials and structures, 40(8), 783-799.

Binici, H., Kaplan, H., \& Yilmaz, S. (2007). Influence of marble and limestone dusts as additives on some mechanical properties of concrete. Scientific Research and Essays, 2(9), 372-379.

Binici, H., Shah, T., Aksogan, O., \& Kaplan, H. (2008). Durability of concrete made with granite and marble as recycle aggregates. Journal of materials processing technology, 208(1), 299-308.

BIS:1489 (1991), Specification for Portland pozzolana cement- (Part-1), Bureau of Indian Standards. New Delhi, India.

BIS:2386 (1963). Methods of Test for Aggregates for Concrete (Part-IV), Bureau of Indian Standards. New Delhi, India.

BIS:383 (1997). Specification for coarse and fine aggregates from natural sources for concrete. Bureau of Indian Standards. New Delhi, India.

BIS:516 (1959). Specification for Methods of Tests for Strength of Concrete, Bureau of Indian Standards, New Delhi, India. 
BIS: 9103 (1999). Specification for Concrete Admixture, Bureau of Indian Standards. New Delhi, India.

De Larrard, F. (2009). Concrete optimisation with regard to packing density and rheology. In $3^{\text {rd }}$ RILEM International Symposium on Rheology of Cement Suspensions such as Fresh concrete, p 8.

DIN-1048 (1991). EN-Testing Concrete, Determination of Depth of Penetration of Water Under Pressure in Hardened Concrete, Berlin, Germany.

Hager, I. (2013). Behaviour of cement concrete at high temperature. Bulletin of the Polish Academy of Sciences: Technical Sciences, 61(1), 145-154.

Hebhoub, H., Aoun, H., Belachia, M., Houari, H., \& Ghorbel, E. (2011). Use of waste marble aggregates in concrete. Construction and Building Materials, 25(3), 1167-1171.

Jain, N., Garg, M., \& Minocha, A. K. (2015). Green Concrete from Sustainable Recycled Coarse Aggregates: Mechanical and Durability Properties. Journal of Waste Management, article ID: 281043, p8.

Kore, S. D., \& Vyas, A. K. (2016-a). Impact of marble waste as coarse aggregate on properties of lean cement concrete. Case Studies in Construction Materials, 4, 85-92.

Kore, SD., \& Vyas, AK. (2016-b). Packing Density Approach for Production of Cost Effective and Durable Concrete, in: Proceedings of the International Conference on Advances in Concrete Technology Materials and Construction, pp. 71-77.

Li, M., Qian, C., \& Sun, W. (2004). Mechanical properties of high-strength concrete after fire. Cement and concrete research, 34(6), 1001-1005.

Marble (2013). Indian Minerals Yearbook, Part- III : Mineral Reviews. 52 ${ }^{\text {nd }}$ Edition final release, Government of India ministry of mines, Indian bureau of mines.

Martins, P., Brito, J. D., Rosa, A., \& Pedro, D. (2014). Mechanical performance of concrete with incorporation of coarse waste from the marble industry. Materials Research, 17(5), 1093-1101.

Mehta, PK., \& Monteiro PJM. (2001). Concrete, microstructure, properties and materials. Second edition, p239.

Mendes, A., Sanjayan, J. G., \& Collins, F. (2011). Effects of slag and cooling method on the progressive deterioration of concrete after exposure to elevated temperatures as in a fire event. Materials and structures, 44(3), 709-718.

Minor Minerals (2014). Department of Mines \& Geology, Udaipur Office wise Report, available at: www.dmgraj.org/docs/STAT2014-15.xls.

MSME (2009). Status report on commercial utilization of marble slurry in Rajasthan. Development Institute, Govt. of India, Ministry of Micro, Small \& Medium Enterprises, p36.

Neville, A. (2004). The confused world of sulfate attack on concrete. Cement and Concrete Research, 34(8), $1275-1296$.

Quiroga, P. N., \& Fowler, D. W. (2004). The effects of aggregates characteristics on the performance of Portland cement concrete (No. ICAR 104-1F,). International Center for Aggregates Research, University of Texas at Austin. 